\title{
Evaluation of Eastern Redcedar Infestations in the Northern Kansas Flint Hills
}

\author{
CLENTON E. OWENSBY, KENNETH R. BLAN, B. J. EATON, AND O. G. RUSS
}

Highlight: Associations among cattle stocking rate, precipitation, and eastern red cedar invasion, and possibly redcedar control measures were investigated. Redcedar numbers generally decreased as stocking rate increased. Precipitation had only a slight effect on invasion rate. Fire, cutting, and fenuron granules appear to effectively kill redcedar.

The recent rapid invasion of eastern redcedar (Juniperus virginiana L.) into tallgrass prairie concerns ranchers and professional range managers.

Redcedars have become prominent since 1960 in areas not occupied previously. Some pastures severely invaded by eastern redcedar join pastures where they are completely absent. Factors involved in rapid invasion by eastern redcedar are not known.

Opinions held by local landowners include a reported large increase in starling (Sturnus vulgaris britannicus Bullough) populations in the early 1960's. Redcedar seeds are spread by various species of birds. Parker (1951) reported starlings as one such species. Some small mammals damage young redcedar seedlings. The decline of some rodent species may have decreased destruction of redcedar seedlings. Government programs promoting eastern redcedar for windbreaks, erosion control, and wildlife cover have increased the seed supply. Both hypotheses may be partially valid, but they cannot be substantiated statistically.

The authors are assistant agronomist, former grad uate research assistant, assistant agronomist, and associate agronomist, Department of Agronomy, Kansas State University, Manhattan.

The research is contribution No. 1240 , Department of Agronomy, Kansas Agr. Exp. Sta., Kansas State University, Manhattan.

Manuscript received July 15, 1972 .
Eastern redcedar is not capable of suckering or resprouting if cut below the bud zone. When the top is cut off below the lowest limb, or is killed by fire, the tree roots usually die from lack of top growth to support them. Fire severely reduces redcedar populations. (Arend, 1950; Dalrymple, 1969).

We investigated the associations among cattle stocking rate, precipitation, and eastern redcedar invasion, and possible control measures.

\section{Study Areas and Methods}

The study area was in the True Prairie of northeast Kansas Flint Hills near Manhattan, Kans. Vegetation was predominantly big and little bluestem (Andropogon gerardi Vitman and $A$. scoparius Michx.), Indiangrass (Sorghastrum nutans (L.) Nash), switchgrass (Panicum virgatum L.), and numerous other less important grasses, forbs, and woody species.

Average annual precipitation at Manhattan was 32 inches during 1959-1969, $69 \%$ during April through September. Average frost-free period is from April 20 to October 10. The elevation of the study pastures is approximately $1,100 \mathrm{ft}$ above mean sea level.

\section{Range Sites}

Soils of the study areas were grouped into range sites to eliminate soil differences. Soil series within a range site have essentially the same plant community and production potential when in climax condition.
Loamy upland range site consists of soils having medium-textured soil deep enough to support primarily big bluestem and Indiangrass in climax condition. Predominant slopes are 1 to $5 \%$.

Limestone breaks consist of soils on predominantly 15 to $30 \%$ slopes. Loss of moisture by runoff is greater than on loamy upland, but the soil is deep enough to support vegetation similar to that found on loamy upland. Limestone rocks usually occur throughout the profile and on the surface.

Clay upland consists of soils on 0 to $3 \%$ slopes mostly on ridges. The soil is finer-textured and more droughty than loamy upland. Vegetation varies widely but includes big and little bluestem with a higher percentage of secondary grasses than on loamy upland.

Limy upland, though similar to loamy upland, has limestone concretions in the profile and on the surface. The soil is deep enough and has water relations that favor vegetation similar to that on loamy upland. Predominant slopes are 3 to $8 \%$.

True Prairie range sites are described in detail by Anderson and Fly (1955).

\section{Main Study Areas}

Eight pastures were selected as main study areas in Riley and Pottawatomie counties to evaluate stocking rates and precipitation effects. Criteria for pasture selection included availability of management records, willingness of landowner to cooperate, and range sites to be studied. Main study areas were all grazed pastures with known management histories for 1960-1968. They ranged from 63 to 237 acres and totaled 1,062 acres. Four study areas had light to moderate invasions of redcedar ( 5 to 20 trees/acre), and four had heavy invasions of eastern redcedar 
$(30+$ trees/acre)

One hundred circular, tenth-acre plots $(37.25 \mathrm{ft}$ diameter) were randomly located in the heavily-invaded pastures; 100 were located in the lightly to moderately-invaded ones. Number of plots in each pasture was in proportion to the pasture size, approximately 1 plot/5 acres.

Information collected on each plot in the main study area included: number of trees, number of trees producing seeds in 1969, tree age, range site, estimated range-condition class, direction of slopc exposure, other brush species present, and estimated abundance of other brush. Cattle stocking rates for each main study pasturc from 1960 through 1969 were recorded.

An additional 100 trees (25 from each range site) were cut to obtain height, diameter, and age of trees in the study areas. Tree height was measured to the nearest inch; diameter was measured to the nearest $1 / 100$ inch at soil level.

\section{Supplemental Pastures}

Thirty supplemental pastures were observed to give the study a broader base. Ten pastures in each of the following categories were selected: essentially no redcedar invasion, light-to-moderate invasion, and heavy invasion of redcedar. Information secured from tenants or landowners for the supplemental pastures included grazing history for 1960-1968, burning history, and a visual estimate of redcedar invasion.

\section{Control Methods}

Foliar-applied herbicides, soil-applied granular herbicides, and controlled burning were tested as control measures. Herbicide treatments were applied to 10 individual trees, each tree a replication in a completely random design.

Foliar-applied herbicides were applied April 9, 1969, with a hand boom attached to a tractor mounted compressed-air sprayer and trees were sprayed until the solution ran off the leaves. Redcedar trees were approximately 1 to 6 inches trunk diameter and 2 to $12 \mathrm{ft}$ tall.

Granular herbicides were applied April 10,1969 , to the soil surface within a $2-\mathrm{ft}$ radius of the base of each tree. Rates were determined by tablespoons of granules per inch of tree trunk diameter at ground level. Trees were approximately 4 to 12 inches in diameter and 10 to $30 \mathrm{ft}$ tall.

Herbicide treatments were cvaluated, and percentage of control was estimated four times during 23 months after application. Control was assessed by dead leaves, branches, and above-ground plant parts affected by treatments. Dead trees were counted 12 to 23 months after treatment to ascertain actual plant kill.

Table 1. Average number of redcedar trees per acre and years established.

\begin{tabular}{lrrrrrrrrrr}
\hline \hline \multirow{2}{*}{$\begin{array}{c}\text { Tree } \\
\text { density }\end{array}$} & 1959 & 1960 & 1961 & 1962 & 1963 & 1964 & 1965 & 1966 & 1967 & 1968 \\
\hline Heavy & 7.8 & 2.0 & 13.2 & 18.0 & 53.5 & 32.2 & 19.0 & 19.8 & 4.2 & 4.2 \\
Light & 0.5 & 0.2 & 0.8 & 0.5 & 3.0 & 3.0 & 0.2 & 3.2 & 2.2 & 2.0 \\
\hline
\end{tabular}

${ }^{1}$ Overall L.S.D. $.05=13.7$.

One pasture was burned April 24, 1971. Range condition was excellent, and the area had an abundance of mulch. The fire traveled with a wind of approximately 3 to $5 \mathrm{mph}$. Individual redcedars were selected throughout the pasture before the fire and were tagged and divided into three size classes for post-fire evaluation. Tree height classes were defined as: seedling trees less than $2 \mathrm{ft}$, small trees 2 to $6 \mathrm{ft}$, and medium trees more than $6 \mathrm{ft}$. Control and apparent kill were assessed by methods identical to those used for herbicide treatments.

\section{Results and Discussion}

Approximately $48 \%$ of the redcedars on the main study areas germinated in 1963 and 1964, and 96\% were less than ten years old. Significant differences in the number of redcedars established among years existed only in the heavily. invaded pastures (Table 1).

Differences among years on the heavily invaded pastures showed a sigmoid population increase curve (Fig. 1). On lightly invaded areas no similar increase occurred.

\section{Effect of Grazing Management}

Management factors other than burning or mechanical removal, which were significantly related to redcedar invasion, included growing-season cattle stocking rates for the year of germination plus grazing the preceding year. Effects of grazing as long as 3 years before the year seed germinated seemed to affect invasion rates. Grazing level apparently influenced the amount of mulch, and indirectly regulated redcedar establishment.

\section{Growing-Season Stocking Rate}

Redcedar invasion rate generally declined as growing-season (May-October) cattle stocking rate increased. That relationship was true on all range sites and pastures as well as for loamy upland and limestone break sites individually. The clay upland and limy upland range sites showed no statistically significant trends with growing-season stocking rate and redcedar invasion. The 1963 redcedar invasion rate declined 6.3 trees per acre per animal-unit-month (AUM) of additional grazing. In 1964 the decline was
13.8 trees per acre per additional AUM of additional grazing (Fig. 2). Redcedar invasion rates were highest during those two years. Heavier stocking rates during the growing season resulted in fewer redcedars.

Redcedar establishment in 1968 did not follow the trend described by Meines (1965) where successful establishment from seed required cool, moist soil. In 1968 heavy grazing during the growing season increased redcedar invasion. Apparently there was a critical amount of soil mulch required for redcedar establishment. Too much or too little mulch seemed to retard redcedar invasion.

\section{Nongrowing-Season Stocking Rate}

Nongrowing-scason stocking rate affected redcedar invasion on some sites in some years. In all cases where a significant trend $(P<0.10)$ was found, an increase in nongrowing-season stocking rate decreased redcedar invasion rate. A slight decrease in redcedar number with increased nongrowing-season stocking rate occurred in 1964 on the lightly invaded pastures and in 1966 on the limestone breaks site in all pastures. Over all sites and pastures in 1967, increases in nongrowing-season stocking rate decreased trees 2.3 per acre for each additional AUM of grazing (Fig. 3). The decreased redcedar invasion rates may have resulted from the decreased mulch left on the soil following winter grazing.

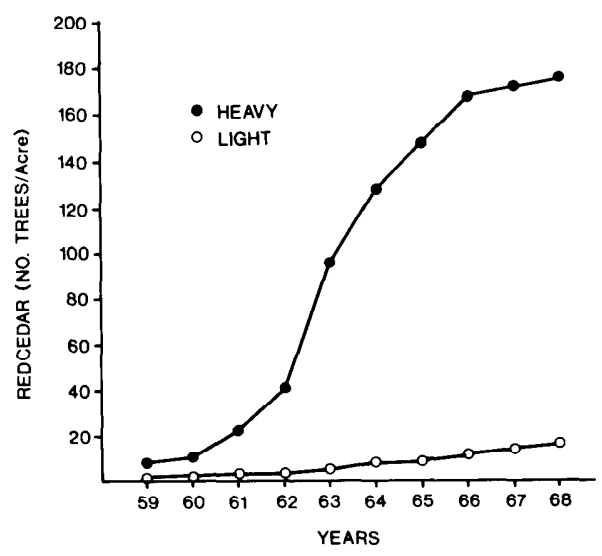

Fig. 1. Cumulative number of redcedar trees per acre on heavily and lightly infested areas from 1959 through 1968. 


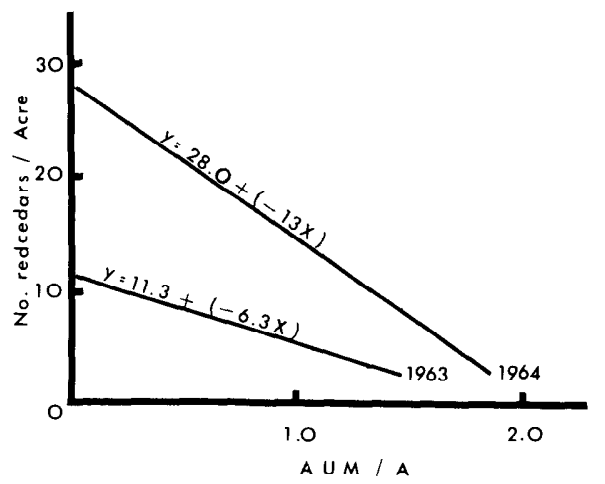

Fig. 2. Relationship between growing-season, cattle-stocking rate, and redcedar numbers over all sites and pastures for 2 years of greatest redcedar invasion.

Less mulch would be expected to result in less redcedar germination and/or survival (Meines, 1965).

\section{Precipitation Effects}

Total precipitation during the year redcedar was established had a statistically significant effect on redcedar invasion. On the heavily invaded areas, for each additional inch of precipitation, invasion rate decreased only 0.2 tree per acre.

The relationship between precipitation and redcedar establishment may be coincidental. The large increase in redcedar in 1963 coincided with an extremely low rainfall year, approximately half of normal. That increase occurred during the accelerated population increasc of an apparent sigmoid population increase curve (Fig. 1). Precipitation in 1964 and 1965 was above average, and redcedar establishment was high both years.

Apparently, redcedar can withstand severe drought in eastern Kansas. In

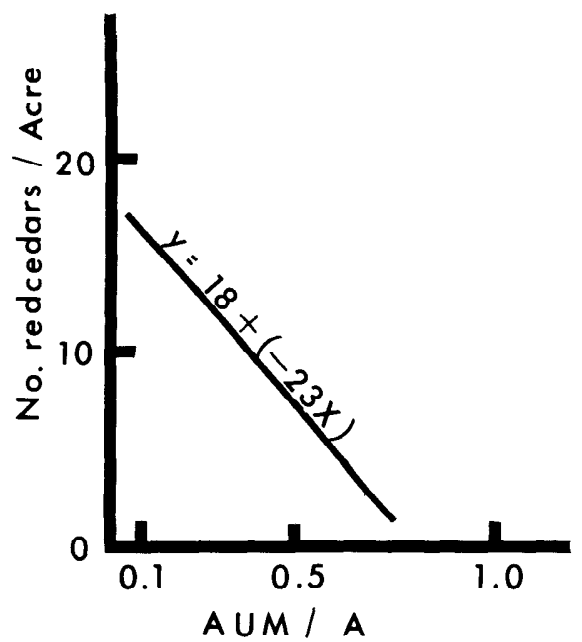

Fig. 3. Relationship between nongrowing-season, cattle-stocking rate, and redcedar invasion for 1967.
Table 2. Frequency (\%) of other woody species in the main study plots. ${ }^{1}$

\begin{tabular}{lcccccccc}
\hline \hline $\begin{array}{l}\text { Redcedar } \\
\text { density }\end{array}$ & $\begin{array}{c}\text { Osage } \\
\text { orange }\end{array}$ & $\begin{array}{c}\text { Buck- } \\
\text { brush }\end{array}$ & $\begin{array}{c}\text { Roughleaf } \\
\text { dogwood }\end{array}$ & Elm & $\begin{array}{c}\text { Honey } \\
\text { locust }\end{array}$ & $\begin{array}{c}\text { Wild } \\
\text { plum }\end{array}$ & $\begin{array}{c}\text { Aromatic } \\
\text { sumac }\end{array}$ & $\begin{array}{c}\text { Smooth } \\
\text { sumac }\end{array}$ \\
\hline Heavy & 4.5 & 25.8 & 25.0 & 1.0 & 4.5 & 3.2 & 14.2 & 52.8 \\
Light & 0.0 & 51.2 & 3.2 & 12.2 & 0.0 & 0.8 & 2.8 & 9.8 \\
\hline
\end{tabular}

${ }^{1}$ Overall L.S.D. $.05=12.4$.
1939, Albertson (1940) reported that up to $80 \%$ of eastern redcedar died near Hays, Kans., in the drought of the 1930's. The three areas he studied were near the western edge of the range of redcedar. Pool (1939) found redcedar in eastern Nebraska had suffered no great damage during the same drought.

Frequency of Occurrence of Associated Brush and Tree Species

Apparently the same factors that retard redcedar invasion generally retard invasion by osage orange (Maclura pomifera Raf.), roughleaf dogwood (Cornus drummondii Meyer), honeylocust (Gleditsia triacanthos L.), and smooth sumac (Rhus glabra L.). Buckbrush (Symphoricarpos orbiculatus Moench), and elm (Ulmus L. sp.) were by redcedar than in heavily invaded pastures (Table 2); however, buckbrush and with no redcedar than on pastures moderately or heavily invaded by redcedar.

Age, Diameter, and Height of Redcedars Correlations

Year of germination compared with average diameter at ground level and height (including 1970 growth until May 7,1970 ) are given in Table 3. Linear regression indicated diameter increased 0.27 inch, and height increased 7.85 inches for each year of age. Range site did not differentially affect redcedar height and diameter in relation to age. more abundant in pastures lightly invaded elm populations were lower on pastures

\section{Slope Exposure}

No significant differences existed among redcedar populations on various slope exposures.

\section{Fire and Cutting}

Fire and cutting were the only factors consistently associated with absencc of redcedar invasion in the 30 supplemental pastures. History of those pastures shows no apparent relationship between stocking rate and redcedar invasion. All pastures free of redcedars had been burned or had redcedars mechanically

\section{Range Sites}

No significant differences in redcedar numbers were found among the loamy upland, limestone breaks, clay upland, and limy upland range sites.

\section{Seed Production}

Trees 6 to 7 years old produced seeds. Secondary invasions from existing trees could occur 6 to 7 years after tree cstablishment.

No detailed information was gathered on proximity of a seed source and its effect on invasion rate.

\section{Foliar Applied Herbicides}

Foliar-applied herbicides partially controlled redcedars but did not kill any (Table 4). Highest rates of picloram and picloram plus $2,4,5-\mathrm{T}$ or $2,4-\mathrm{D}$ were more phytotoxic than other treatments at 4 and 8 -month interval evaluations. Results removed.

Table 3. Age (years), diameter (inch), and height (inch) of redcedars from loamy upland, limy upland, clay upland, and limestone breaks range sites.

\begin{tabular}{ccccccc}
\hline $\begin{array}{c}\text { Year of } \\
\text { germination }\end{array}$ & Age & $\begin{array}{c}\text { Average diameter } \\
\text { at ground level }\end{array}$ & $\begin{array}{c}\text { Average } \\
\text { height }\end{array}$ & $\begin{array}{c}\text { Range of } \\
\text { diameters }\end{array}$ & $\begin{array}{c}\text { Range of } \\
\text { heights }\end{array}$ & $\begin{array}{c}\text { No. in this } \\
\text { age class } \\
\text { sample }\end{array}$ \\
\hline 1969 & & 0.04 & 2.0 & 0 & 0 & 3 \\
1968 & 1 & 0.12 & 8 & - & - & 1 \\
1967 & 2 & 0.28 & 12.5 & $0.20-0.23$ & $11-15$ & 4 \\
1966 & 3 & 0.47 & 20.2 & $0.31-0.67$ & $12-24$ & 9 \\
1965 & 4 & 0.71 & 26.1 & $0.51-1.18$ & $16-42$ & 7 \\
1964 & 5 & 0.84 & 30.3 & $0.63-1.26$ & $21-47$ & 8 \\
1963 & 6 & 1.12 & 43.4 & $0.83-1.89$ & $24-64$ & 28 \\
1962 & 7 & 1.60 & 58.2 & $1.06-2.28$ & $29-75$ & 15 \\
1961 & 8 & 1.62 & 57.4 & $0.47-2.48$ & $30-76$ & 14 \\
1960 & 9 & 2.32 & 73.3 & $0.94-3.07$ & $24-90$ & 7 \\
1959 & 10 & 3.27 & 84.5 & $3.15-3.39$ & $79-90$ & 2 \\
1958 & 11 & 2.13 & 70.0 & - & - & 1 \\
1957 & 12 & 3.03 & 80.0 & 3.0 & $80-83$ & 2 \\
\hline
\end{tabular}


Table 4. Control $(\%)$ and actual kill of eastern redcedars after application of herbicides (lb aihg) in foliage-wetting sprays.

\begin{tabular}{|c|c|c|c|c|c|c|}
\hline \multirow[b]{2}{*}{ Treatment - Rate $^{1}$} & \multicolumn{4}{|c|}{ Percent control } & \multicolumn{2}{|c|}{$\begin{array}{l}\text { Number of } \\
\text { dead trees }\end{array}$} \\
\hline & $4 \mathrm{mo}$ & $8 \mathrm{mo}$ & $12 \mathrm{mo}$ & $23 \mathrm{mo}$ & $12 \mathrm{mo}$ & $23 \mathrm{mo}$ \\
\hline Picloram 0.5 & $6 c^{2}$ & $15 \mathrm{de}$ & $9 \mathrm{~cd}$ & $24 \mathrm{ab}$ & 0 & 0 \\
\hline Picloram 1.0 & $33 b$ & 55 a & $40 a$ & 39 a & 0 & 0 \\
\hline Picloram $+2,4,5-\mathrm{T}(0.5+0.5)$ & $12 \mathrm{c}$ & $23 b c$ & $9 \mathrm{~cd}$ & $21 \mathrm{abc}$ & 0 & 0 \\
\hline Picloram $+2,4,5-\mathrm{T}(1+1)$ & $47 \mathrm{a}$ & 38 abc & $25 \mathrm{abc}$ & $21 \mathrm{abc}$ & 0 & 0 \\
\hline Picloram + 2,4-D $(0.5+1)$ & $5 \mathrm{c}$ & $19 \mathrm{~cd}$ & $9 \mathrm{~cd}$ & $15 b c$ & 0 & 0 \\
\hline Picloram + 2,4-D $(1+2)$ & $43 \mathrm{ab}$ & $41 \mathrm{ab}$ & $27 \mathrm{ab}$ & 38 a & 0 & 0 \\
\hline \multicolumn{7}{|l|}{ Picloram + Amitrole + } \\
\hline $\mathrm{NH}_{4} \mathrm{CHN}(0.5+1+0.9)$ & $10 \mathrm{c}$ & 17 cde & $9 \mathrm{~cd}$ & $19 \mathrm{abc}$ & 0 & 0 \\
\hline Picloram + Banvel $(0.5+1)$ & $7 \mathrm{c}$ & $34 \mathrm{abcd}$ & $15 \mathrm{bcd}$ & $38 \mathrm{a}$ & 0 & 0 \\
\hline Control & $0 \mathrm{c}$ & $1 \mathrm{e}$ & $0 \mathrm{~d}$ & $1 \mathrm{c}$ & 0 & 0 \\
\hline
\end{tabular}

${ }^{1}$ Pounds active ingredient per 100 gal water carrier.

${ }^{2}$ Numbers in a column followed by a common letter do not differ significantly $(P<0.05)$.

Table 5. Control (\%) and actual kill of eastern redcedar af ter application (tbs/inch basal diameter) of granular herbicides.

\begin{tabular}{|c|c|c|c|c|c|c|c|c|}
\hline \multirow[b]{2}{*}{ Treatment } & \multirow[b]{2}{*}{$\% \mathrm{ai}^{1}$} & \multirow[b]{2}{*}{ Rate } & \multicolumn{4}{|c|}{$\%$ control } & \multicolumn{2}{|c|}{ No. of dead trees } \\
\hline & & & $4 \mathrm{mo}$ & $8 \mathrm{mo}$ & $12 \mathrm{mo}$ & $23 \mathrm{mo}$ & $12 \mathrm{mo}$ & $23 \mathrm{mo}$ \\
\hline Fenuron & 25 & 0.25 & $17 \mathrm{e}^{2}$ & $23 d$ & $14 \mathrm{~cd}$ & $14 \mathrm{e}$ & $0 \mathrm{c}$ & $0 \mathrm{c}$ \\
\hline Fenuron & 25 & 0.5 & $42 \mathrm{~d}$ & $29 \mathrm{~d}$ & $17 \mathrm{c}$ & $36 \mathrm{~d}$ & $0 \mathrm{c}$ & $0 \mathrm{c}$ \\
\hline Fenuron & 25 & 1.0 & $80 \mathrm{~b}$ & $75 \mathrm{~b}$ & $84 \mathrm{a}$ & $90 \mathrm{ab}$ & $1 \mathrm{c}$ & $3 b$ \\
\hline Fenuron & 25 & 2.0 & $99 a$ & 99 a & $100 \mathrm{a}$ & $100 \mathrm{a}$ & $10 \mathrm{a}$ & $10 \mathrm{a}$ \\
\hline Picloram & 2 & 1.0 & $46 d$ & $46 \mathrm{c}$ & $59 \mathrm{~b}$ & $70 \mathrm{c}$ & $0 \mathrm{c}$ & $1 \mathrm{bc}$ \\
\hline Picloram & 2 & 2.0 & $65 \mathrm{c}$ & $69 \mathrm{~b}$ & $59 \mathrm{~b}$ & $80 \mathrm{bc}$ & $0 \mathrm{c}$ & $2 \mathrm{bc}$ \\
\hline Karbutilate & 10 & 1.0 & $62 \mathrm{c}$ & $74 \mathrm{~b}$ & $85 \mathrm{a}$ & $96 \mathrm{a}$ & $4 \mathrm{~b}$ & $8 a$ \\
\hline Karbutilate & 10 & 2.0 & $71 \mathrm{bc}$ & $75 \mathrm{~b}$ & 99 a & $100 \mathrm{a}$ & 9 a & $10 \mathrm{a}$ \\
\hline Control & & 0 & $0 \mathrm{f}$ & $0 \mathrm{e}$ & $0 \mathrm{~d}$ & $0 \mathrm{f}$ & $0 \mathrm{c}$ & $0 \mathrm{c}$ \\
\hline
\end{tabular}

${ }^{1}$ Percent active ingredients in commercial formulations.

${ }^{2}$ Numbers followed by a common letter do not differ significantly.

from foliar-applied herbicides 23 months after treatment did not differ significantly, but all differed from the control.

Watson and Wiltse (1964), Dalrymple (1969), and Buehring et al. (1971) found foliar-applied picloram satisfactorily controlled redcedar. Their picloram in combination with 2,4-D, 2,4,5-T, dicamba, and amitrol plus $\mathrm{NH}_{4} \mathrm{CN}$ at rates comparable to rates we used gave similar results. The data suggest that redcedar either does not absorb foliar-applied herbicides well enough to kill the plant or that quantities absorbed are not translocated to the roots. Cuticle wax could be a barrier to absorption.

Herbicide granules (Table 5) controlled redcedar more effectively than foliar sprays. Fenuron, picloram, and karbutilate granules at 1-2 tbs/inch basal diameter gave 70 to $100 \%$ redcedar control 23 months after treatment. Fenuron at 1 to 2 tbs/inch basal diameter effectively controlled redcedar, while rates of 0.25 to 0.5 tbs/inch basal diameter did not. Fenuron applied at 2.0 tbs/inch basal diameter killed all redcedars, but 1.0 tbs/inch basal diameter killed only $30 \%$ of them.

Picloram granules gave slightly less redcedar control than the highest rates of fenuron and karbutilate; however picloram granules were only $2 \%$ a.i. compared with $25 \%$ a.i. and $10 \%$ a.i. for fenuron and karbutilate. Picloram granules controlled redcedar much more effectively than foliar sprays. Karbutilate granules effectively controlled redcedars at 1 and $2 \mathrm{tbs} /$ inch basal diameter. Both rates gave high control by killing plants, as shown 23 months after application.

\section{Control by Fire}

Small redcedars were affected more by fire than larger trees (Table 6). Fire controlled $89 \%$ of seedlings. Fewer trees more than 6 feet tall were killed by fire than seedlings or trees less than six feet tall. Fire controlled $83 \%$ of small trees. Fire controlled $39 \%$ of medium trees.

Main study pasture 1 in the precipitation-and-stocking-rate study was burned in April 1969. Dead redcedars that could still be identified were in-
Table 6. Control (\%) and number of dead trees per acre of eastern redcedar $4 \mathrm{mo}$ after burn.

\begin{tabular}{lccc}
\hline $\begin{array}{l}\text { Tree } \\
\text { size }^{1}\end{array}$ & $\begin{array}{c}\text { Sample } \\
\text { size }\end{array}$ & $\begin{array}{c}\text { Percent } \\
\text { control }\end{array}$ & $\begin{array}{c}\text { Number of } \\
\text { dead trees }\end{array}$ \\
\hline Seedlings & 25 & 89 & 18 \\
Small & 25 & 83 & 12 \\
Medium & 10 & 39 & 2 \\
\hline
\end{tabular}

${ }^{1}$ Seedlings, less than $2 \mathrm{ft}$ tall; small, 2-6 ft tall; medium, taller than $6 \mathrm{ft}$.

cluded in the count. Many smaller seedlings probably were consumed and, therefore, were not included. That was the only main study pasture burned between 1960 and 1970 . Redcedars killed by that fire were counted. Approximately $63 \%$ of all age classes were dead.

These and other data (Dalrymple, 1969) suggest that small redcedars can be effectively eliminated by fire, but to control larger trees an alternative measure such as a herbicide treatment or mechanical removal is usually required. Some fires kill redcedar trees up to 20 feet high. Research on proper timing and amount of combustible material is needed.

\section{Conclusions}

1. Redcedar were most restricted by fire or cutting.

2. Heavier stocking rates seemed to reduce redcedars in the bluestem growing season as well as in the dormant period.

3. Redcedars appeared to invade all upland range sites equally.

4. Slope exposure did not significantly alter redcedar populations.

5. Invasion of redcedars was accompanied by other brushy species.

6. Redcedars 6 to 7 years old produced seeds.

7. Redcedars in the study area grew approximately 0.27 inch in diameter and 7.85 inches in height yearly.

8. Herbicide granules controlled redcedar more effectively than foliar sprays.

\section{Literature Cited}

Albertson, F.W. 1940. Studies of eastern redcedar in west-central Kansas. Kansas Acad. Sci. Trans. 43:85-95.

Anderson, K.L., and C.L. Fly. 1955. Vegetation-soil relationships in Flint Hills bluestem pastures. J. Range Manage. 8:1963-1969.

Arend, J. L. 1950. Influence of fire and soil on distribution of eastern redcedar in the Ozarks. J. Forest. 48:129-130.

Buehring, Normie, P.W. Santelmann, and Harry M. Elwell. 1971. Responses of eastern redcedar to control procedures. J. Range Manage. 24:378-384.

Dalrymple, R. L. 1969. Cedar control in southern Oklahoma. S. Weed Conf. 22:272-273. 
Meines, M. K. 1965. Juniper (Juniperus virginiana L.) germination simplified. U.S. Dep. Agr., Forest Service. Washington. Tree Planters Notes No. 70.

Parker, J. 1951. Natural reproduction from redcedar. J. Forest. 49:285.

Pool, R. G. 1939. Some reactions of the vegetation in the towns and cities of $\mathrm{Ne}$ braska to the great drought. Univ. of Neb. Bull. quoted in Torry Bot. Club.
$66: 457-464$.

Watson, A. J., and M. G. Wiltse. 1964. Tordon

for brush control on utility right-of-way in the Eastern United States. Down to Earth 19(1):11-14. 